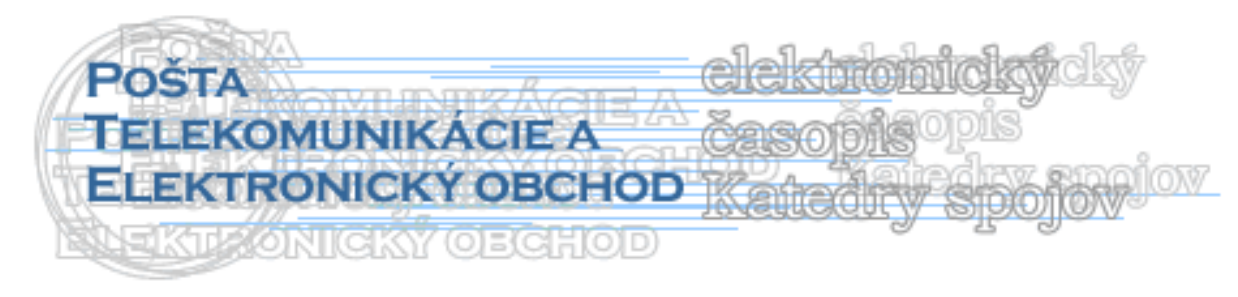

\title{
PROTIKORUPČNÝ PROGRAM DAŇOVÉHO RIADITELSTVA SLOVENSKEJ REPUBLIKY
}

\author{
Zuzana Janušková*
}

Korupcia $\mathrm{v}$ daňovom systéme je vážnym spoločenským problémom nás všetkých. Obdobie zrodu novej modernej daňovej sústavy Slovenskej republiky nesie so sebou niekol'ko rozporuplných, negatívnych i kontraproduktívnych znakov, medzi ktoré nesporne patrí aj realita etablovania a pretrvávajúceho výskytu korupcie. Hoci predpokladáme, že mnoho pracovníkov daňových orgánov je čestných, nájdu sa aj jedinci, ktorí svoje postavenie zneužívajú. V rámci uvedeného systému sa tak korupcia vyskytuje nielen medzi niektorými pracovníkmi daňových orgánov t.j. medzi pracovníkmi všetkých zložiek Ústredného daňového riaditel'stva (ÚDR SR) vrátane daňových úradov (DÚ), ale aj medzi niektorými pracovníkmi ostatných článkov podiel'ajúcich sa na realizácii výkonu daňového systému SR napr. správcovia dane s nehnutel'nosti na obecných úradoch alebo členovia daňovej sekcie MF SR.

Podl'a doterajších skúseností z daňovej, podnikatel'skej i hospodárskej praxe boli oficiálne i neoficiálne prezentované desiatky prípadov korupcie. To potvrdzuje, že tento negatívny jav - ako súčast' rozsiahlej korupcie zistenej v štátnej správe SR všeobecne pretrváva aj v daňovom systéme.

Najčastejšie sa používa definícia, že korupcia je zneužitie moci nad cudzím, zvereným majetkom, či právami s ciel'om získania osobných, súkromných výhod. Pod súkromnými výhodami sa rozumejú nielen výhody získané priamo pre osobu, ktorá zneužila zverenú moc, ale aj výhody, ktoré takýmto správaním mohla zabezpečit’ pre iné osoby - rodinných príslušníkov či priatel'ov a známych.

Formy korupcie, s ktorými sa môžeme stretnút', sú :

> úplatkárstvo (akákol'vek neoprávnená výhoda obvykle vyčíslitel’ná v peniazoch),

$>$ podplácanie,

$>$ zneužitie právomoci verejného činitel'a,

> konflikt záujmov ( ide o situáciu, kedy z dôvodov osobných alebo iných obdobných vzt’ahov zainteresovaných osôb je narušený alebo ohrozený záujem na nestrannom a objektívnom výkone týchto činností),

$>$ klientelizmus (zvýhodňovanie známych) a nepotizmus (zvýhodňovanie príbuzných).

\footnotetext{
* Ing. Zuzana Janušková, Daňový úrad Žilina I, Janka Král’a 2, 01001 Žilina tel.: 041/5047361

e-mail: zuzana.januskova@za.drsr.sk
} 
Riziká korupčného správania v rámci daňovej správy možno klasifikovat' na:

$>$ vonkajšie

$>$ vnútorné

$>$ všeobecné

Vonkajšie riziká sú svojou povahou premenlivé a menia sa v závislosti od konkrétnej situácie či prostredia. Príčiny vzniku vonkajších rizík spočívajú spravidla v správaní sa daňových subjektov a prostredí, v ktorom sa správa daní vykonáva (napr. spoločenský status zamestnancov daňovej správy a ich porovnávanie so zamestnancami iných štátnych organizácii). Existencia vonkajších rizík má priamy dopad na vznik, resp. uvedomovanie si existencie vnútorných rizík.

\section{Systémové chyby napomáhajúce rastu korupcie daňových orgánov}

Korupcia v daňových orgánoch vzniká pod vplyvom subjektívnych i objektívnych príčin. Pokial abstrahujeme od subjektívnej podstaty korupčného správania, teda od osobných štandardov čestnosti a morálky pracovníkov daňových orgánov, existuje niekol'ko objektívnych dôvodov, prečo je korupcii na daňových úradoch vytvorený priestor pre existenciu. Medzi hlavné patria:

$>$ absencia výkonu kvalifikačných testov, ktoré by sa mali vykonávat' v 2-ročných intervaloch. V SR sa takéto kvalifikačné testy nerobia, výučbou i skúškami na Daňovej škole ÚDR SR v Banskej Bystrici prechádzajú len novoprijatí adepti,

$>$ absencia komplexného personálneho auditu pracovníkov daňových orgánov minimálne v 4-ročných intervaloch so samozrejmost'ou psychologických testov,

$>$ podcenenie možnej produkcie zdrojov pre verejné financie štátu pri hodnotnom odmeňovacom systéme daňových orgánov,

$>$ absencia razantnejšej práce daňovej inšpekcie a absencia tzv. agentov provokatérov aj v daňovom konaní,

$>$ absencia tzv. registra skorumpovaných daňových úradníkov s mediálnou kampaňou zistených a preukázaných prípadov,

$>$ neexistencia tzv. finančných súdnych dvorov, kde by existovali sudcovia - experti na dane i daňovú problematiku a mäkký režim postihov za daňové úniky a daňové podvody v Trestnom zákone SR,

$>$ vysoká tolerancia štátu voči skrytej ekonomike. Optimistické odhady hovoria o priemernom objeme minimálne cca 50 miliárd ročne. Existencia, rast a latentný prístup k riešeniu uvedeného problému dodáva odvahu všetkým štátnym úradníkom vrátane daňových prijímat' úplatky a iné korupčné plnenia.

\section{Najrizikovejšie pracovné pozície vo vzt’ahu ku korupcii}

Pracovníkov daňových orgánov okrem stredného a top-manažmentu možno rozdelit' pri abstrahovaní od minima hospodársko-správnych pracovníkov na dve hlavné najpočetnejšie skupiny - t.j. na správcov dane a na daňových kontrolórov.

Vo vzt’ahu ku korupcii sú najrizikovejšími skupinami:

riaditelia daňových úradov,

$>$ daňoví kontrolóri. 
Tieto pracovné pozície sú najviac „atakované“ zo strany daňových subjektov, aby participovali na zakrývaní a „odpúšt’aní“ zistených daňových rozdielov a eliminovaní očakávaných potenciálnych daňových dorubov a sprievodných finančných sankcií.

\section{Riaditelia daňových úradov}

Je všeobecne známe, že riaditelia daňových úradov sú funkcie obsadzované po politickej linke, často na úkor odbornosti. Následne tak podliehajú okrem priameho tlaku podnikatel'ov (daňových subjektov), aj nepriamemu lobbingu a zastrašovaniu zo strany „tých, čo ich tam dostali a na revanš vyžadujú rôzne protislužby."

Riaditelia daňových úradov, $\mathrm{v}$ rámci potreby obnovy $\mathrm{MTZ}$, ktorá je značne nevyhovujúca (zastarané budovy, autopark, počítačový systém, interiér, atd'.), spolurozhodujú o verejnej sútaži pri výbere stavebných firiem na stavbu nových budov daňových úradov, kde je predpoklad vel'kého úplatkárstva. Vo výberových konaniach tak často uspeje v rámci širokej konkurencie práve „dotyčná“ stavebná firma.

\section{Daňoví kontrolóri}

Za hlavné príčiny vzniku korupcie pri činnosti daňových kontrolórov na daňových úradoch možno považovat' predovšetkým:

> nedocenenie spoločenskej prestíže a sociálneho statusu daňového kontrolóra $\mathrm{v}$ spoločnosti v porovnaní so štandardnými ekonomikami a vyspelými demokraciami,

$>$ nízke mzdové ocenenie, neadresné a netransparentné stimulovanie pilierových pracovníkov, kde aj najlepší kontrolóri sú v porovnaní s najslabšími nepodstatne odlíšení pri odmeňovaní,

$>$ mimoriadna náročnost' na vedomostný fundament a neustála potreba systematickej inovácie vedomostí,

$>$ sebareflexia z poznania legislatívnych dier v SR ,

> nerealizovanie tzv. zákona o štátnej službe $\mathrm{v}$ dikcii priaznivo nasmerovanej ku pracovníkom daňových orgánov, kde by bol zakotvený komplexne moderne poňatý inštitút tzv. „definitívy.”

V rámci profesijnej orientácie jednotlivých daňových kontrolórov najrizikovejšou skupinou sa javia evidentne pracovníci kontrolujúci daň z príjmov právnických i fyzických osôb a daň z pridanej hodnoty.

\section{Rozdiely medzi daňami i lokalitami}

Z hl'adiska objemu finančných transferov a významu daní z hl'adiska „dotácií“ verejných financií štátu sa najdôležitejšie javia daň z príjmov a daň z pridanej hodnoty. Doterajší časový rad vývoja daňového inkasa za roky 1993-1998 dokumentuje, že najväčšie daňové nedoplatky sú práve na dani z príjmov právnických osôb (dominantne spoločnosti s ručením obmedzeným a akciové spoločnosti) a na dani $\mathrm{z}$ pridanej hodnoty. Hoci kvalifikované odhady daňových únikov v SR sa rôznia, viacerí odborníci sa prikláňajú $\mathrm{k}$ názoru, že tieto oscilujú okolo hranice minimálne cca 30 miliárd ročne, pričom objem evidovaných daňových nedoplatkov štátu túto hranicu už dávno prekročil a vzrastajúci trend daňovej nedisciplinovanosti sa zatial' nedarí ani potlačit', ale ani stabilizovat'. Tieto dlhodobo 
verejne známe dáta indikujú a evokujú často aj u daňových kontrolórov nálady, že štát nemá záujem alebo nedokáže riešit' tieto negatívne javy.

V kontexte rozdielov životných nákladov medzi menšími lokalitami (napr. okresné mestá a menšie mestečká) a vel'kými lokalitami (Bratislava, centrá krajov a mestá nad 50.000 obyvatel'ov) treba vnímat' aj rozdiely $\mathrm{v}$ životnej úrovni jednotlivých daňových kontrolórov pri relatívne rovnakom mzdovom ocenení. Preto platí, že podstatná čast' korupčných aktivít daňových kontrolórov sa deje vo vel'kých lokalitách s vyššou mierou anonymity (a menším rizikom prezradenia), neodhalenými nátlakovými, zastrašovacími a vydieračskými aktivitami z kategórie racketingu. Daňový kontrolór v Námestove alebo Ružomberku (kde každý každého pozná) sa $\mathrm{s}$ menšou pravdepodobnost'ou opováži vziat' úplatok $\mathrm{v}$ porovnaní $\mathrm{s}$ daňovým kontrolórom $\mathrm{v}$ Bratislave. Napríklad aj preto, že $\mathrm{v}$ prípade straty zamestnania daňového kontrolóra $v$ regióne Oravy, kde je 22\%-ná nezamestnanost', si ho tento znovu len vel'mi t’ažko nájde v porovnaní s kontrolórom z Bratislavy, kde je 4\%-ná nezamestnanost' s ovel'a širšou ponukou na trhu vol'ných pracovných príležitostí. Ak je napr. daňový kontrolór v Bratislave živitel'om rodiny s tromi det'mi a jeho manželka je na materskej dovolenke (abstrahujeme od možnosti, že nemajú vlastný byt), tak zo svojho platu (predpokladajme vo výške 13.000 brutto) nedokáže vlastnej rodine ponúknut' ani len pokrytie základných životných potrieb. Čo naopak kontrolór z rovnakého príkladu žijúci v Námestove (kde sú ovel'a nižšie životné náklady) zatial' dokáže ako-tak pokryt'.

\section{Používané techniky}

V doterajšej praxi sú zaznamenané viaceré alternatívy „techniky korumpovania daňových úradníkov.” V princípe ich môžeme rozdelit’ na finančné a naturálne plnenie, ktoré sa líšia v jednotlivých kauzách i lokalitách. Úplatkárstvo má v slovenskej praxi aj voči daňovým kontrolórom vel'mi vel'a prejavov - od „drobných darov charakteru všimného“ cez prijatie diet'at'a kontrolóra do prosperujúcej firmy dotyčného daňového subjektu až po rôzne nepriame „sponzorstvá“ a priame finančné „,dary“ t.j. úplatky.

Okrem uvedených techník, ktoré sú častejšie najmä pri dani z príjmov, existujú aj mnohé iné, kde rozdielny prístup je najmä pri dani z pridanej hodnoty. Tu existuje možnost' vracania nadmerných odpočtov DPH, kedy predpoklad intenzity priebežnej (nie periodickej) kontroly zo strany daňového úradu je ovel’a vyššia. Preto sú okrem daňových kontrolórov miestami podplácaní aj správcovia dane s ciel’om zabezpečit' to, aby príslušný nadmerný odpočet danému daňovému subjektu zo štátnych peňazí čo najskôr uhradili.

Okrem prezentovaných foriem priamej daňovej korupcie existuje aj jemnejšia forma nepriamej korupcie. Tá spočíva najmä $\mathrm{v}$ tom, že mnohí daňoví kontrolóri ovládajú daňové účtovníctvo a často krát ho vedú so sprievodným čiernym daňovým poradenstvom za odmenu pre daňové subjekty. Pritom ho mnohokrát vedú priamo pre tie subjekty, ktoré kontrolujú.

Ďalším priestorom pre korupciu je poplatok za tzv. urýchlenú, resp. vyžiadanú daňovú kontrolu, ktorá sa uskutočňuje na základe potreby daňového subjektu mat' lepšie obchodné renomé pre banky a súčasne sa vyhnút' viacročnej tzv. prenosovej chybe.

Pri správe daní riziká korupcie hrozia napr. pri: 
registrácii daňových subjektov,

> vystavovaní rôznych potvrdení, výpisov (napr. potvrdenia o výške nedoplatkov pre účely získania úverov, dotácií, grantov), vystavovanie výkazov nedoplatkov vzhl'adom na časový aspekt,

> vypracovaní odporúčajúcich stanovísk pre účely poskytovania regionálnej štátnej pomoci uplatňovanej formou úl'avy na dani z príjmov, povol'ovaní odkladov, splátok, poskytnutí odpustení,

$>$ posudzovaní žiadostí o odpustenie sankcie, povolenie úl'avy zo sankcie alebo odpustení daňového nedoplatku, povol'ovanie odkladov a splátok daní,

$>$ určení preddavkov správcom dane na dani z príjmu inak; ukladaní pokút a vyrubovaní sankcií.

Pri zabezpečení a vymáhaní nedoplatkov napr. pri:

uplatňovaní záložného práva,

$>$ daňovom exekučnom konaní (termín začatia konania, neprimeranost' úkonov),

$>$ výkone dražieb hnutel'ného aj nehnutel'ného majetku.

Pri poskytovaní služieb verejnosti napr. pri:

vypracovávaní stanovísk pre daňové subjekty (sú záväzné aj pri daňovej kontrole).

Pri dozorovaní prevádzkovania hazardných hier napr. pri:

> opakovanom vykonávaní dozoru u tých istých prevádzok, u toho istého prevádzkovatel'a hazardných hier tým istým zamestnancom štátneho dozoru,

> spolupráci prevádzkovatel'a so zamestnancom ŠD pri vedomom prehliadaní nepovolenej hry.

Pri rozhodovacom procese napr. pri:

> riešení námietok podaných daňovým subjektom,

$>$ konaniach o riadnych aj mimoriadnych opravných prostriedkoch,

$>$ verejnom obstarávaní.

Vnútorné riziká sú riziká v organizačných zložkách daňovej správy. Ide najmä o činnosti pri spravovaní jednotlivých druhov daní daňových subjektov pri správe daní, daňovej kontrole, vymáhaní daňových nedoplatkov ako i pri metodike daní, vo všetkých oblastiach rozhodovacieho procesu daňových orgánov.

Všeobecné riziká sú také riziká, ktoré sa prelínajú všetkými činnost'ami správy daní a v rôznej miere sa podiel'ajú na vznikajúcich rizikách v jednotlivých oblastiach správy daní:

\section{Pri práci s l’udskými zdrojmi napr.:}

stabilita manažmentu, riadenie a organizácia práce,

$>$ nedostatok tzv. stavovskej hrdosti zamestnancov daňovej správy,

$>$ zarad'ovanie blízkych príbuzných do priamej riadiacej pôsobnosti, resp. tak aby jeden podliehal pokladničnej alebo účtovej kontrole druhého,

$>$ nedostatky v komunikácii. 


\section{Pri práci s informačnou technikou napr.:}

zneužitie nedostatkov APV DIS,

$>$ zverejnenie prístupových hesiel.

\section{Pri práci s legislatívou napr.:}

pri legislatívnych úpravách so slovom „môže“ ktoré umožňujú alternatívne konanie.

Strategickým ciel’om daňovej správy je pretransformovat' daňovú správu SR na modernú a efektívnu správu, ktorá zabezpečí efektívny výber daní, dodržuje podmienky spravodlivosti, svojím konaním ul'ahčuje daňovým subjektom dobrovol'né plnenie ich daňových záväzkov a zároveň vytvára podmienky pre efektívny systém manažmentu l'udských zdrojov, a ktorá vytvorí vhodné konkurenčné a sociálne prostredie pre rozvoj a rast vlastných zamestnancov. Pri dodržiavaní a presadzovaní princípov morálky a etiky, sa zaväzuje presadzovat' základné etické princípy a dodržiavat' prijaté protikorupčné opatrenia.

Naplnením tohto ciel’a je aj Protikorupčný program DR SR. Jeho hlavným ciel’om je obmedzovat' korupciu:

demonštrovaním záväzku neprijímat' úplatky,

> zvyšovaním transparentnosti v konaní a rozhodovaní zamestnancov daňovej správy pri plnení úloh daňových orgánov.

Zamestnanci daňovej správy sa zaväzujú neprijímat' úplatky v žiadnej forme a zaväzujú sa zrieknut' využitia iných spôsobov na prijímanie alebo poskytovanie neprimeranej výhody daňovým subjektom, dodávatel'om, sprostredkovatel'om, zamestnancom alebo predstavitel'om orgánov verejnej správy. Zároveň sa zaväzujú nezneužívat' svoje pracovné zaradenie a právomoci s tým spojené na konanie, ktoré je alebo môže byt' v rozpore s platnými právnymi predpismi a vnútornými predpismi daňovej správy. Každý zamestnanec daňovej správy sa zaväzuje oznámit' svojmu nadriadenému alebo vedeniu pokusy o korupciu. Vedenie daňovej správy sa zaväzuje neodkladne sa takýmto podozrením zaoberat' a v prípade jeho opodstatnenosti oznámit' to orgánom činným v trestnom konaní.

Zamestnanci daňových orgánov majú pri plnení úloh postavenie verejných činitel'ov. Podnety a podozrenia nasvedčujúce zneužitiu právomoci, mareniu úloh a korupcie sú predmetom kontrolnej činnosti antikorupčného oddelenia, ako i súčast'ou riadiacej práce predstavených a vedúcich zamestnancov.

$\mathrm{S}$ účinnostou od 14.8.2006 bola schválená Smernica upravujúca jednotný postup pri podozrení zo zneužitia právomoci, marenia úloh a korupcie zamestnancov daňových orgánov č. 11/2006/130, prvoradou úlohou všetkých dotknutých zamestnancov je jej dôsledné dodržiavanie.

\section{Literatúra:}

[1] interné materiály daňovej správy

[2] Korupcia v daňovom systéme a na daňových úradoch [online] [cit 7.7. 2010] Dostupné na internete: < http://www.dane.sk/news/korupcia-na-danovych-uradoch-sprava1> 